\title{
AN ATTEMPT TO IDENTIFY TRAFFIC RELATED ELEMENTS IN SNOW
}

\author{
Ewa ADAMIEC ${ }^{1}$, Robert WIESZAŁA ${ }^{2}$, \\ Magdalena STRZEBOŃSKA ${ }^{1}$ \\ \& Elżbieta JAROSZ-KRZEMIŃSKA ${ }^{1}$
}

\author{
${ }^{1}$ AGH University of Science and Technology; \\ al. Mickiewicza 30, 30-059 Krakow, Poland; \\ e-mail: eadamiec@agh.edu.pl \\ ${ }^{2}$ SUT Silesian University of Technology; Faculty of Transport, \\ ul Akademicka 2A, 44-100 Gliwice, Poland; \\ e-mail: Robert.Wieszala@polsl.pl
}

\begin{abstract}
The main objective of this article is an attempt to use snow as an indicator in the process of assessing and identifying vehicle-derived elements pollution. The aim of the present study is to characterize traffic-related elements in snow collected from three sites: a parking place, a highway and a relatively unpolluted airfield. Several recent studies suggest that road traffic is considered to be one of the major sources of environmental pollution in urban areas. In order to avoid the problem of low emission from household furnaces, samples were collected far away from residential buildings. Snow located near roads with heavy traffic seems to be a very useful tool and indicator of trafficrelated elements released into the environment. Snow acts as a natural filter for various chemical elements and particles. Snow is an efficient scavenger of aerosol and air pollutants, usually remains on the ground for sampling after the event; moreover, snowmelt contaminates soil. In the present study filtered $(0.45 \mu \mathrm{m})$ samples of melted snow were analyzed with ICP-MS. The results show significantly higher concentrations of elements in snow collected at the parking lot and at the highway when compared to samples taken from a relatively unpolluted airfield. Research on exploitation dust (break, tire, clutch) was performed with SEM-EDS.
\end{abstract}

Key words: traffic, parking lot, snow, vehicle-derived elements 


\section{INTRODUCTION}

Snow collected from sites located in the vicinity of roads with heavy traffic seems to be a very useful tool and indicator of traffic-related elements released to the environment. Road traffic is associated with significant emissions of vehicle-derived elements contaminating soil and water, and at the moment is less controllable than other anthropogenic activities such as power plants, metallurgy and/or mining.

During springtime, melting snow and roadway runoffs significantly affect the receiving soil-water environment and river systems. Transport rate and travel distance of elements increase substantially when they reach river environments. In the terrestrial environment, metals and metalloil can penetrate deep below the surface and pollute groundwater. As a result, traffic-related pollution leads to a number of consequences for living organisms; for example some elements bioaccumulate in ecosystems (Basta et al. 2005). Studies of the chemical composition of snow as an indicator of anthropogenic environment pollution have increased in recent years due to higher awareness of health risks associated with its contamination with heavy metals. Similar research on snow contamination was carried out in China by Hu et al. (2012). The results obtained in the study have been presented in Table 1.

Table 1

Statistical parameters of selected heavy elements concentrations in snow - Beijing

\begin{tabular}{|c|c|c|c|c|c|c|c|}
\hline \multirow{2}{*}{ Statistical parameters } & \multicolumn{7}{|c|}{ Elements concentration $[\mu \mathrm{g} / \mathrm{L}]$} \\
\cline { 2 - 8 } & $\mathrm{Al}$ & $\mathrm{Mn}$ & $\mathrm{Cu}$ & $\mathrm{Zn}$ & $\mathrm{As}$ & $\mathrm{Sb}$ & $\mathrm{Ba}$ \\
\hline Min & N.D. & 1.16 & N.D. & 3.91 & N.D. & 0.548 & 2.80 \\
\hline Max & 4.41 & 54.60 & 9.630 & 71.30 & 3.361 & 2.860 & 65.90 \\
\hline Average & 1.75 & 15.80 & 1.340 & 36.60 & 0.878 & 1.230 & 17.10 \\
\hline Median & 1.19 & 12.90 & 0.687 & 35.60 & 0.766 & 1.150 & 13.40 \\
\hline
\end{tabular}

N.D. - not detected.

After analyzing PAHs in snow and moss, Viskari et al. (1997) confirmed that snow appears to be a good collector of pollutants from the atmosphere and can be used to monitor local airborne pollution from road traffic. Similarly, extensive research on PAH related to deposition of motor vehicle emission along roadside was carried out by Hautala et al. (1997). Bizzotto et al. (2009) ran studies on glacial and non-glacialfed streams to evaluate the loading of persistent organic pollutants (PCBs, HCB, HCHs and DDTs) accumulated in Alpine glaciers through seasonal snow/ice melt. A significant number of studies have been focused on natural areas attractive for tourists. Highly interesting results have been obtained in extensive research focusing on heavy metals in winter snow in the Dolomites; its statistical analysis of natural and anthropogenic contributions has been presented by Gabrielli et al. (2008). Magill \& Sansalone (2010) analyzed particulate-bound metals for source area 
snow in the Lake Tahoe watershed. Sansalone \& Buchberger (1996) analyzed distribution of traffic related metals and solids in urban highway snow and spring rainfall-runoff. Furthermore, Sansalone et al. (2003) ran detailed research on physical and chemical characteristics of deposition material generated from traffic activities after the melting as well as transport of the snow from the pavement shoulder. Reinosdotter \& Viklander (2005) analyzed snow in Swedish municipalities, focusing on metals in melted water and particulate matter as well as granulometric analysis of urban snow residuals generated from traffic activities quality. Westerlund \& Viklander (2006) reported concentrations of particles in different size fractions in snow and associated metals in road runoff during snowmelt and rainfall. Significant body of research has been focused on platinum-group elements (Rh, Pt, Pd) in snow. Platinum group elements $(\mathrm{Pd}, \mathrm{Rh})$, rare earth elements $(\mathrm{Ce}, \mathrm{Y}), \mathrm{Ir}, \mathrm{Os}, \mathrm{Zr}$, As as well as $\mathrm{Ce}, \mathrm{Rb}$ are associated primarily with the exploitation of catalytic converters. Platinum group elements and rare earth elements are extensively used as components of automobile catalytic converters. PGE has been reported to bioaccumulate in the environment and cause allergic reactions and various health problems. Palacios et al. (2000), Leśniewska et al. (2004) and Ward \& Dudding (2004) in detail describe PGE distribution in different environmental samples (indicators) in many cities all over the world. A significant correlation of $\mathrm{Pt}, \mathrm{Pd}, \mathrm{Rh}$ indicates a common source for these metals. PGE correlate positively with $\mathrm{Ce}, \mathrm{Zr}$, Hf and Y - these positive inter-element correlations identify traffic as the main sources of PGE. Gregurek et al. (1999) analyzed Rh, Pt, Pd and Au in snow samples from the Kola Peninsula in Russia. Snow sampling has been used to assess the load of anthropogenic emissions and as an indicator to determine environmental loads of specific point sources, such as concentrating smelters and power plants (Ettala et al. 1986, Gregurek et al. 1998).

In order to understand the impact of road traffic emission on the environment, it is important to analyze and evaluate pollution originating through the wear of frictional elements in vehicles. Sampling in winter allows us to obtain representative samples of snow which is a good indicator of traffic derived elements, because it does not contain soil and other contaminants from the surrounding areas. Road dust contains potentially toxic pollutants originating from urban land uses and soil inputs from surrounding areas. Recent studies have shown that road dust primarily consists of soil derived minerals $(60 \%)$ with quartz averaging $40-50 \%$ and the remainder being clay forming minerals of albite, microcline, chlorite and muscovite originating from surrounding soils. Organic matter primarily originating from plant matter constitutes about $2 \%$ of road dust, while potentially toxic pollutants represent about $30 \%$ of the build-up. These pollutants originate from brake and tire wear, combustion emissions and fly ash from asphalt. Heavy metals such as $\mathrm{Zn}, \mathrm{Cu}, \mathrm{Pb}, \mathrm{Ni}, \mathrm{Cr}$ and $\mathrm{Cd}$ primarily originate from vehicular traffic while $\mathrm{Fe}, \mathrm{Al}$ and $\mathrm{Mn}$ mainly come from surrounding soils (Gunawardana et al. 2011).

Break materials and additives can be grouped according to their expected functions in the following categories: abrasives, friction modifiers, filters and reinforcements and binder materials. Today, friction materials in vehicle brake lining consist of a wide 
range of compounds, with fibers of steel, glass and plastic serving as reinforcements. Some compounds are used for their heat-conducting properties (brass chips) and good filling properties. Break dust consists mainly of particulate $\mathrm{Al}, \mathrm{Si}, \mathrm{S}, \mathrm{Ti}, \mathrm{Fe}$ as well as $\mathrm{Cd}, \mathrm{Cr}, \mathrm{Ni}$, $\mathrm{Pb}$ and $\mathrm{Zn}$ (Adachi \& Tainosho 2004, Hjortenkrans et al. 2007). Iron alloys also contain traces of $\mathrm{S}, \mathrm{Cu}, \mathrm{Sb}$ and $\mathrm{Ba}$; some brake dust samples analyzed by researchers contained $\mathrm{Zr}, \mathrm{Cu}$ to control heat transport, $\mathrm{Sb}$ to enhance stability and $\mathrm{BaSO}_{4}$ to increase the density of the break pad (Blau \& Meyer 2003, Hjortenkrans et al. 2006). Standard brake pads consist of: $48 \%$ barite, $14 \%$ vermiculite, $19 \%$ phenolic resin, $4.6 \%$ antminite, $7.5 \%$ rubber, $6.4 \%$ aramide, $0.3 \%$ sulphur. Österle et al. (2001) described chemical and microstructural changes induced by friction and wear of brakes, whereas composition, functions and testing of friction brake materials and their additives have been discussed in detail in Blau (2001). Typical composition of brake materials and additive functionality is presented in Table 2 (compiled based on Blau 2001).

Table 2

Brake materials and additive functionality

\begin{tabular}{|c|c|c|}
\hline $\begin{array}{l}\text { Material } \\
\text { characteristics }\end{array}$ & Composition and consequences & Reference \\
\hline Aluminum oxide & $\begin{array}{l}\text { Hydrated form added as a polishing agent and for wear } \\
\text { resistance, anhydrous form is more abrasive, fused is very } \\
\text { hard and is most abrasive form }\end{array}$ & Nicholson 1995 \\
\hline Iron oxide & $\begin{array}{c}\text { Hematite }\left(\mathrm{Fe}_{2} \mathrm{O}_{3}\right) \text { and magnetite } \\
\text { abrasive }\end{array}$ & Nicholson 1995 \\
\hline Quartz & Crashed mineral particles & Erikssoon 2000 \\
\hline Silica & May be natural or synthetically produced & Hooton 1969 \\
\hline $\begin{array}{l}\text { Zirconium } \\
\text { silicate }\end{array}$ & $\mathrm{ZrSiO}_{4}$ & Jang 2000 \\
\hline Graphite & $\begin{array}{c}\text { Used as a powder to control heat transport but can cause } \\
\text { excessive cast iron wear }\end{array}$ & $\begin{array}{c}\text { Spurr 1972, } \\
\text { Nicholson } 1995\end{array}$ \\
\hline $\begin{array}{l}\text { Ceramic } \\
\text { microspheres }\end{array}$ & $\begin{array}{l}\text { Used as a powder to control heat transport but can cause } \\
\text { excessive cast iron wear }\end{array}$ & $\begin{array}{l}\text { PQ Corporation } \\
1993\end{array}$ \\
\hline Copper & $\begin{array}{c}\text { Used as a powder to control heat transport but can cause } \\
\text { excessive cast iron wear }\end{array}$ & Nicholson 1995 \\
\hline Friction powder & $\begin{array}{c}\text { May consist of Fe sponge, e.g. for semi-metallic brake } \\
\text { pads, a number of particle sizes are available depending on } \\
\text { requirements for surface area }\end{array}$ & Hoegenase 1990 \\
\hline Lead oxide & $\mathrm{PbO}$ has been used as friction modifier & Nicholson 1995 \\
\hline $\begin{array}{l}\text { Metals-fluxing } \\
\text { compounds }\end{array}$ & $\begin{array}{c}\mathrm{Pb}, \mathrm{Sb}, \mathrm{Bi}, \mathrm{Mo} \text { as fluxing compounds serve as oxygen getters } \\
\text { to stabilize friction-induced films. }\end{array}$ & Hooton 1969 \\
\hline
\end{tabular}


Table 2 cont.

\begin{tabular}{|c|c|c|}
\hline Metal oxides & $\begin{array}{l}\text { Magnetite }\left(\mathrm{Fe}_{3} \mathrm{O}_{4}\right) \text { improves cold friction. } \mathrm{ZnO} \text { lubricates but } \\
\text { can cause drum polishing. } \mathrm{Cr}_{2} \mathrm{O}_{3} \text { raises friction }\end{array}$ & $\begin{array}{l}\text { Gudmand-Hoyer } \\
\text { et al. } 1999\end{array}$ \\
\hline Metal sulfides & $\begin{array}{c}\text { PbS soft solids lubricant additive ( } 2-8 \text { mass } \%), \\
\mathrm{MoS}_{2}(3-8 \text { mass } \%), \mathrm{ZnS} \text { recommended for high load } \\
\text { temperatures (5-10 mass \%), metal sulfides mixtures } \\
\text { are also used }\end{array}$ & BBU 1993 \\
\hline $\begin{array}{l}\text { Antimony } \\
\text { sulfides }\end{array}$ & Solid lubricant added to enhance frictional stability $\left(>450^{\circ} \mathrm{C}\right)$ & Young 2000 \\
\hline Brass & $\begin{array}{l}62 \% \mathrm{Cu}, 38 \% \mathrm{Zn} \text {, improves wet friction and recovery, } \\
\text { common additive, sometimes used as chips }\end{array}$ & Nicholson 1995 \\
\hline Antioxidant & $\begin{array}{l}\text { Graphite is commonly used in metal-ceramic composite } \\
\text { brakes }\end{array}$ & Hooton 1969 \\
\hline Barium sulfate & $\begin{array}{l}\text { Increases density and may aid in wear resistance, stable at } \\
\text { high temperature }\end{array}$ & Nicholson 1995 \\
\hline $\begin{array}{l}\text { Fibers }- \text { mixed } \\
\quad \text { oxide }\end{array}$ & $\begin{array}{c}\text { A mixture of silca ( } 45-50 \text { mass } \%) \text {, alumina ( } 5-15 \text { mass } \%) \text {, } \\
\text { calcia ( } 34-42 \text { mass } \%) \text {, magnesia ( } 3-10 \text { mass } \%) \text { and other } \\
\text { inorganics }(0-7 \text { mass } \%) \text {; function is to control fade } \\
\text { and increase braking effectiveness }\end{array}$ & Sloss (no year) \\
\hline Lime & $\mathrm{CaOH}_{2}$ is used to avoid corrosion in $\mathrm{Fe}$-additives & Nicholson 1995 \\
\hline $\begin{array}{l}\text { Potassium } \\
\text { titanate }\end{array}$ & Inert filler material; often used instead of asbestos & Young 2000 \\
\hline Zinc oxide & Imparts some wear resistance, but can polish drums & Nicholson 1995 \\
\hline
\end{tabular}

A description of more than 100 formulations of patented friction materials was presented by Newman (1978). Fauser et al. (1999), Adachi \& Tainoshob (2004), and Schauer et al. (2006) confirmed that tire dust contains significant amounts of $\mathrm{Zn}, \mathrm{Cd}, \mathrm{Co}, \mathrm{Cr}, \mathrm{Cu}, \mathrm{Hg}$, $\mathrm{Mn}, \mathrm{Mo}, \mathrm{Ni}$ and $\mathrm{Pb}$. Snow is an efficient scavenger of air pollutants and it usually remains on the ground for sampling after the event. With rising temperatures pollution contained in snowmelt contaminates soil. Vasić et al. (2012) performed correlation analysis between concentration of metals and fine particles with the diameter lower than a few $\mu \mathrm{m}$ that stay suspended in snowmelt. The fine particles mass consisted of elements mainly originating from anthropogenic sources, and this conclusion was supported by the statistically significant positive correlation between $\mathrm{Fe}, \mathrm{Zn}$ and $\mathrm{Al}$ and fine particles mass based on distribution parameters. In their earlier research the authors performed brake dust characteristics (Wieszała \&Wyciślik 2008).

Granulometric analysis of dust formed through exploitation of the frictional parts of the car revealed that over $88 \%$ of the dust consist of particles in a fraction of up to $56 \mu \mathrm{m}$. Fractions under $20 \mu \mathrm{m}$, which have been found to present the highest health risk, form $17 \%$ of the exploitation dust. 


\section{STUDY AREAS AND SAMPLING}

The aim of this study is to estimate the concentration of traffic-related metals in melted snow. Surface snow samples (about $20 \mathrm{~cm}$ depth) have been collected from three open fields: five samples were taken from $1 \mathrm{~m}^{2}$ and then averaged. The first sampling point at the highway is located in Ruda Śląska-Halemba. There are three highway lanes in each direction. Highway test section is straight with the volume of traffic averaging at about 60 thousand vehicles per day, of which about $30 \%$ are trucks and coaches. The selected section of the highway is located at a considerable distance from both industrial plants and residential houses. Samples were collected at a distance of 3 meters away from the edge of the roadway. The next sampling point was located at the entrance to the parking lot in Katowice, Pukowca Street, at a distance of $1.5 \mathrm{~m}$ from the edge of the roadway. During the weekend this site serves more than 3 thousand vehicles, mainly individual cars. Speed at the parking lot is minimal and should be classified as starting speed. This particular location at the entrance to the parking lot has been selected also due to the fact that here cars form traffic jams while waiting to join the road. The third sampling point was located in close vicinity to an old airfield Katowice-Muchowiec surrounded by forest (huge meadow) at a distance of $300 \mathrm{~m}$ away from any road. Nearby there are no factories, houses or any other emission sources.

\section{METHODS}

Researchers focused on As, Ba, Be, Bi, Cd, Co, Cr, Cs, Cu, Fe, Mn, Mo, Ni, Pb, Rb, $\mathrm{Sb}, \mathrm{Te}, \mathrm{Ti}, \mathrm{Tl}, \mathrm{V}, \mathrm{W}, \mathrm{Zn}$ and $\mathrm{Zr}$. In each sampling point field duplicates of snow samples were collected. Elements have been determined with ICP-MS application. In order to obtain unambiguous and unbiased ICP-MS results, the above-mentioned elements were additionally measured by ICP-OES, while $\mathrm{Zn}, \mathrm{Pb}, \mathrm{Fe}, \mathrm{Cu}$ and $\mathrm{Cd}$ were measured by AAS. In order to estimate the accuracy and bias of the analytical method used in the study, reagents blanks and certificated reference material $1643 \mathrm{~d}$ were used to assure that analytical results meet the required criteria. Table 3 presents detection limits for ICP-MS.

Table 3

Detection limits for ICP-MS

\begin{tabular}{|c|c|}
\hline Element & Detection limits $[\mathrm{mg} / \mathrm{L}]$ \\
\hline $\mathrm{As}$ & 0.01 \\
\hline $\mathrm{Be}$ & 0.01 \\
\hline $\mathrm{Ba}$ & 0.002 \\
\hline $\mathrm{Bi}$ & 0.001 \\
\hline $\mathrm{Cd}$ & 0.01 \\
\hline $\mathrm{Co}$ & 0.0005 \\
\hline
\end{tabular}


Table 3 cont.

\begin{tabular}{|c|c|}
\hline $\mathrm{Cr}$ & 0.04 \\
\hline $\mathrm{Cu}$ & 0.01 \\
\hline $\mathrm{Fe}$ & 0.01 \\
\hline $\mathrm{Mo}$ & 0.01 \\
\hline $\mathrm{Mn}$ & 0.0002 \\
\hline $\mathrm{Ni}$ & 0.01 \\
\hline $\mathrm{Pb}$ & 0.002 \\
\hline $\mathrm{Pd}$ & 0.01 \\
\hline $\mathrm{Sn}$ & 0.01 \\
\hline $\mathrm{Tl}$ & 0.001 \\
\hline $\mathrm{V}$ & 0.004 \\
\hline $\mathrm{W}$ & 0.002 \\
\hline $\mathrm{Zn}$ & 0.0002 \\
\hline $\mathrm{Zr}$ & 0.01 \\
\hline
\end{tabular}

\section{RESULTS}

Concentrations of elements obtained in the analysis of melted snow samples have been presented in Table 4.

Table 4

Concentrations of elements in melted snow samples

\begin{tabular}{|c|c|c|c|}
\hline \multirow{2}{*}{ Element } & \multicolumn{3}{|c|}{ Concentration $[\mu \mathrm{g} / \mathrm{L}]$} \\
\cline { 2 - 4 } & airfield & highway & parking lot \\
\hline $\mathrm{As}$ & 2.61 & 6.66 & 4.32 \\
\hline $\mathrm{Ba}$ & 5.63 & 8.71 & 10.10 \\
\hline $\mathrm{Be}$ & N.D. & 56.7 & 17.3 \\
\hline $\mathrm{Bi}$ & 44.6 & 74.2 & 17.3 \\
\hline $\mathrm{Cd}$ & 0.10 & 1.29 & 4.16 \\
\hline $\mathrm{Co}$ & 10.80 & 9.50 & 1.57 \\
\hline $\mathrm{Cr}$ & 3.62 & 3.15 & 17.04 \\
\hline $\mathrm{Cs}$ & 2.04 & 1.89 & 12.90 \\
\hline $\mathrm{Cu}$ & 3.16 & 7.14 & 6.33 \\
\hline $\mathrm{Fe}$ & 15.5 & 22.7 & 392.0 \\
\hline $\mathrm{Mn}$ & 4.19 & 1.29 & 6.38 \\
\hline
\end{tabular}


Table 4 cont.

\begin{tabular}{|c|c|c|c|}
\hline \multirow{2}{*}{ Element } & \multicolumn{3}{|c|}{ Concentration $[\mu \mathrm{g} / \mathrm{L}]$} \\
\cline { 2 - 4 } & airfield & highway & parking lot \\
\hline $\mathrm{Mo}$ & 24.3 & 18.3 & 179.0 \\
\hline $\mathrm{Ni}$ & 4.40 & 5.59 & 4.18 \\
\hline $\mathrm{Pb}$ & 1.30 & 1.84 & 0.86 \\
\hline $\mathrm{Rb}$ & 5.03 & 5.77 & 1.96 \\
\hline $\mathrm{Sb}$ & 6.83 & 13.06 & 11.40 \\
\hline $\mathrm{Te}$ & 2.65 & 2.55 & 3.57 \\
\hline $\mathrm{Ti}$ & 4.71 & 6.82 & 5.91 \\
\hline $\mathrm{Tl}$ & 6.47 & 7.19 & 10.00 \\
\hline $\mathrm{V}$ & 2.19 & 4.27 & 18.00 \\
\hline $\mathrm{W}$ & 1.70 & 2.59 & 1.93 \\
\hline $\mathrm{Zn}$ & 2.58 & 9.37 & 25.70 \\
\hline $\mathrm{Zr}$ & 9.12 & 26.65 & 9.90 \\
\hline
\end{tabular}

N.D. - not detected.

Very high concentration of $\mathrm{Zn}$ (up to $25.7 \mu \mathrm{g} / \mathrm{L}$ ) was found in samples collected in the parking lot. Such high concentration most likely was caused by tire wear. These samples also contained very high concentrations of $\mathrm{Fe}$ and $\mathrm{Cr}$. These findings suggest that the main source of pollution was tire as well as brake-pad and clutch-plate wear. High concentrations of $\mathrm{Zr}$, Ti and $\mathrm{Sb}$ are connected with friction modifiers, matrix and fillers. Predictably, the analysis of samples collected at the parking lot showed high concentrations of these elements.

Full scale counts: 855
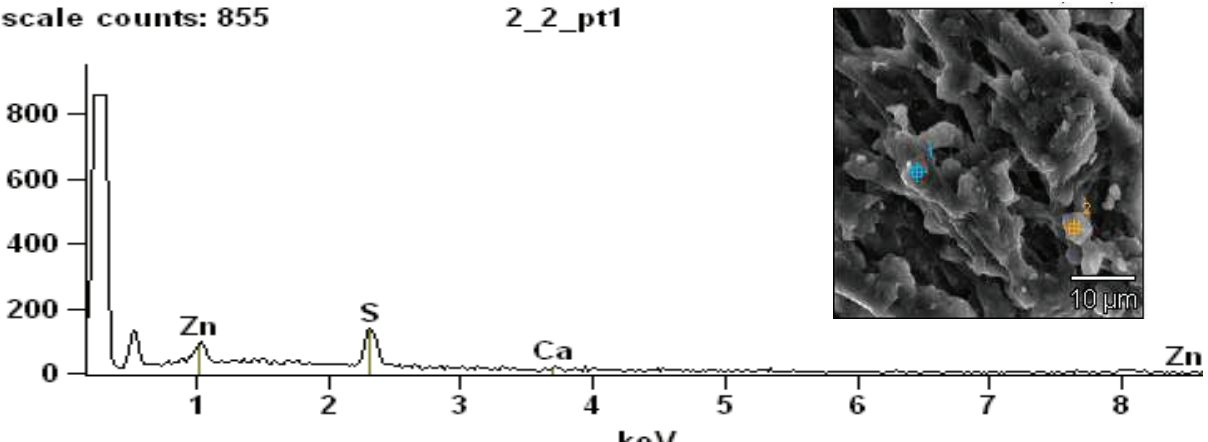

Fig. 1. Tire-derived - exploitation dust (fraction below $20 \mu \mathrm{m}$ ). Micro-photo of the surface (SEM) with a magnification $2000 \times$ spectrum characteristic of X radiation (EDS) (Wieszała 2006) 
The characteristics of exploitation dust coming from a tire was shown in Figure 1. The research was conducted with the use of scanning microscope SEM: S4200 (HITACHI) in the following experimental conditions: the energy of primary electron beam $15 \mathrm{keV}$, cold cathode with field emission, the intensity of absorption current $1 \cdot 10^{-10} \mathrm{~A}$. In order to take a micro-photo of the dust a signal of secondary electrons (SEM) was used. A magnification from $50 \times$ to $8000 \times$ was used. To the analysis of chemical composition of the dust a X-ray spectrometer with energy dispersion cooperating with a microscope was used (EDS): VOYAGER (NORAN, detector Si-Li, thin polymer window). During the tests a presence of such chemical elements was proved: $\mathrm{Zn}, \mathrm{S}$ and $\mathrm{Ca}$.

Micro-photo of exploitation dust coming from a break pads was shown in Figure 2. Dust coming from a car brake contains such elements as $\mathrm{Cr}, \mathrm{Fe}, \mathrm{Cu}, \mathrm{Zn}, \mathrm{Mg}, \mathrm{Al}, \mathrm{Si}, \mathrm{Zr}$, Sn and $\mathrm{Cr}$.

Full scale counts: 2214
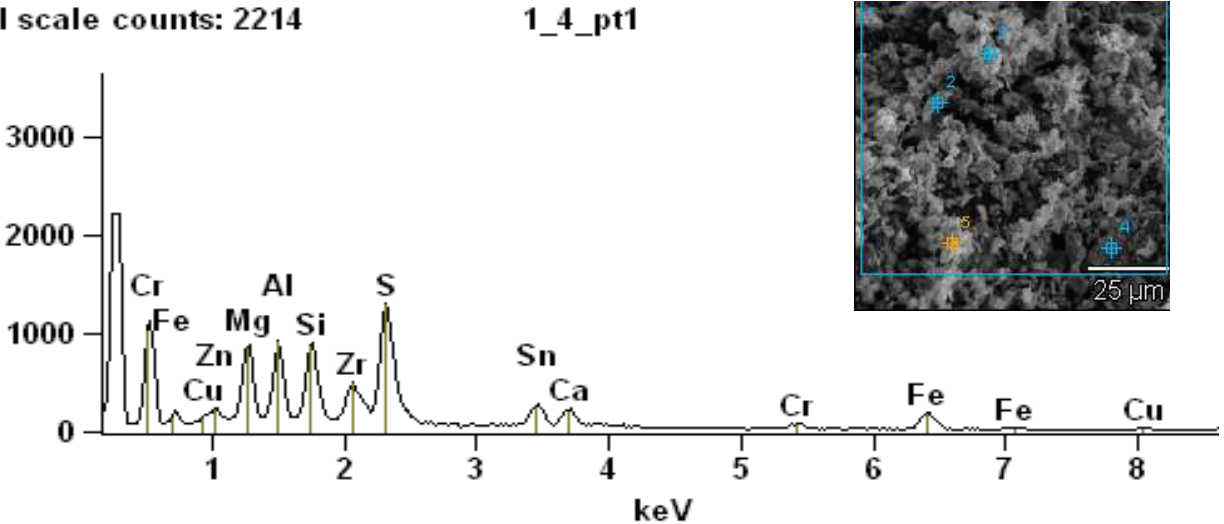

Fig. 2. Break-pads - exploitation dust (fraction below $20 \mu \mathrm{m}$ ). Micro-photo of the surface (SEM) with a magnification 1000× spectrum characteristic of X radiation (EDS) (Gajdzik et al. 2012)

Full scale counts: 326
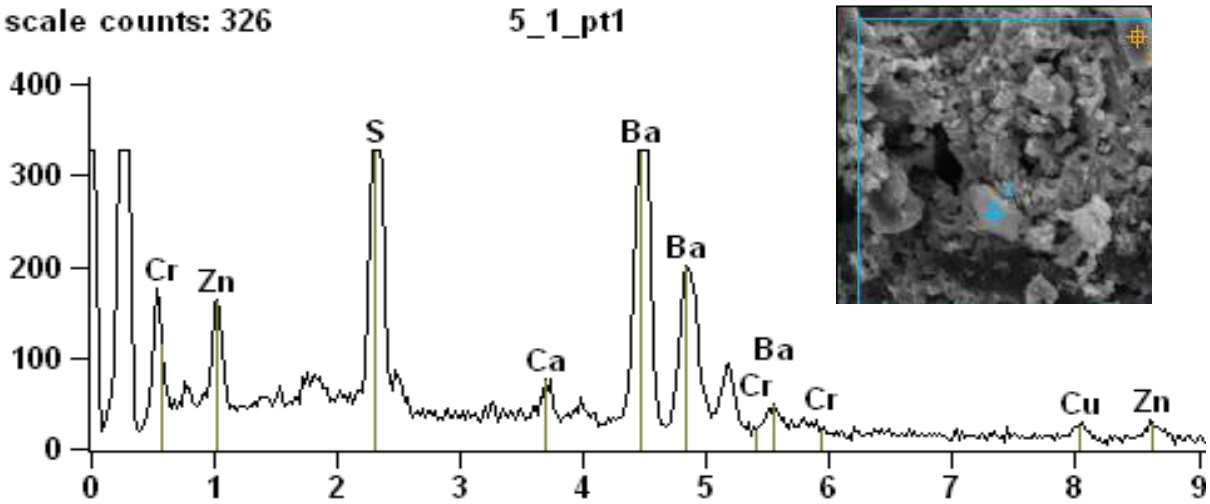

keV

Fig. 3. Clutch plates - exploitation dust. Micro-photo of the surface (SEM) with a magnification $2000 \times$ spectrum characteristic of $X$ radiation (EDS) (Gajdzik et al. 2012) 
Relatively high concentrations of $\mathrm{As}, \mathrm{Ce}, \mathrm{Cr}$ and $\mathrm{Zr}$ seem to be typical for dust produced in the process of catalytic converter exploitation. The highest concentration of the above mentioned elements was found in dust samples collected on the highway. Clutch dust, in turn, contains significant amounts of $\mathrm{Cr}, \mathrm{Cd}, \mathrm{Cu}, \mathrm{Pb}, \mathrm{Ba}, \mathrm{Sb}$ and $\mathrm{Zn}$ (see Fig. 3).

\section{CONCLUSIONS}

Snow is a good indicator of elements dissolved in snow which can later on easily penetrate into soil and water. Concentrations of elements analyzed in the study have been shown to be higher in samples collected on the highway and parking lot than in samples from a relatively unpolluted airfield areas in Katowice-Muchowiec. The fact of particular importance is that high concentrations of $\mathrm{Cs}, \mathrm{Sb}, \mathrm{Zr}, \mathrm{Zn}, \mathrm{Cr}$ and As have been found in snow samples from the parking lot in Katowice, Pukowca Street and the highway in Ruda Śląska-Halemba. Composition of elements found in contaminated samples may be a useful indicator of the source of pollution. The main sources of exploitation pollution formed in the process of vehicle operation are vehicle specific places: brake systems, tires, clutch plates and the erosion of the active layer of catalytic converters. Based on its composition, pollution found in samples collected on the highway seems to be predictably related to exploitation of catalytic converters, whereas elements found in contaminated samples from the parking lot are associated with tire, brake-pad and clutch-plate wear. Thus the composition of road pollution varies and seems to depend on the type of vehicle exploitation predominant in a given location.

Further research is indicated to analyze particulate matter in snow, focusing on geochemical composition and phase analysis in order to determine the proportion of elements in melted snow and particulate matter. In order to determine various forms of metals and estimate amount of metals that can be released from particulate matter to the soil-water environment - TCLP and BCR procedure should be performed. The Authors are fully conscious of the limitations associated with the process of sample collection. This study is exploratory in character more conclusive results will be obtained in model studies accounting for precise number of vehicles passing through the sampling area and "trap" sampling collection.

The studies were carried out within the research activities of the Faculty of Geology, Geophysics and Environment Protection at the AGH University of Science and Technology, Department of Environment Protection, Project no. 11.11.140.199.

\section{REFERENCES}

Adachia K. \& Tainoshob Y., 2004. Characterization of heavy metal particles embedded in tire dust. Environment International, 30, 1009-1017.

Apeagyei E., Bank M.S. \& Spengler J.D., 2011. Distribution of heavy metals in road dust along an urban-rural gradient in Massachusetts. Atmospheric Environment, 45, 13, 2310-2323. 
Basta N.T., Ryan J.R. \& Chaney R.L., 2005. Heavy metal and trace element chemistry in residual-treated soil: a review of impacts on metal bioavailability and sustainable land application, Journal of Environmental Quality, 34, 1, 49-63.

BBU Chemie GmBH 2004 [company materials].

Bizzotto E.C., Villa S., Vaj C. \& Vighi M., 2009. Comparison of glacial and non-glacial-fed streams to evaluate the loading of persistent organic pollutants through seasonal snow/ ice melt. Chemosphere, 74, 924-930.

Blau P. \& Meyer H., 2003. Characteristics of wear particles produced during friction tests of conventional and unconventional disc brake materials. Wear, 255, 1261-1269.

Blau P., 2001. Compositions, functions, and testing of friction brake materials and their their addatives. Oak Ridge National Laboratory UT-B Attelle, Report ORNL/M-5824 for U.S. Department of Energy, 3-24.

Blau P., 2003. Microstructure and detachment mechanism of friction layers on the surface of brake shoes. Journal of Materials Engineering and Performance, 12, 1, 56-60.

Ettala M., Kukkamäki E. \& Tamminen A., 1986. The use of vertical snow sampling as an indicator of some emissions from point sources. Aqua Fennica, 16, 91-108.

Fauser P., Tjell J.C., Mosbaek H. \& Pilegaard K., 1999. Quantification of tire-tread particles using extractable organic zinc as tracer. Rubber Chemical Technology, 72, 969-977.

Gabrielli P., Cozzi G., Torcini S., Cescon P. \& Barbante C., 2008. Trace elements in winter snow of the Dolomites (Italy): a statistical study of natural and anthropogenic contributions. Chemosphere, 72, 1504-1509.

Gajdzik B., Wieszała R. \& Wieczorek T., 2012. Identification of the exploitation dust in road dust. Metalurgija, 50, 2, 101-104.

Gregurek D., Melcher F. \& Niskavaara H., 1999. Platinum-group elements (Rh, Pt, Pd) and Au distribution in snow samples from the Kola Peninsula, NW Russia. Atmospheric Environment, 33, 3281-3290.

Gregurek D., Reimann C. \& Stumpfl E.F., 1998. Trace elements and precious metals in snow samples from the immediate vicinity of nickel processing plants, Kola Peninsula, Northwest Russia. Environmental Pollution, 102, 221-232.

Gudmand-Hoyer A., Bach A., Neilsen G.T. \& Per M., 1999. Tribiological properties of automotive disc brakes with solids lubricants. Wear, 232, 168-175.

Gunawardana Ch., Goonetilleke A., Egodawatta P. \& Dawes L., 2012. Source characterisation of road dust based on chemical and mineralogical composition. Chemosphere, 87, 2, 163-170.

Hautala E.L., Rekilä R., Tarhanen J. \& Ruuskanenb J., 1995. Deposition of motor vehicle emissions and winter maintenance along roadside assessed by snow analyses. Environmental Pollution, 87, 45-49.

Hjortenkrans D.S.T., Bergbäck B.G. \& Häggerud A.V., 2006. New metal emission patterns in road traffic environments. Environmental Monitoring and Assessment, 117, 85-98. 
Hjortenkrans D.S.T., Bergbäck B.G. \& Häggerud A.V., 2007. Metal emissions from brake linings and tires: case studies of Stockholm, Sweden 1995/1998 and 2005. Environmental Science \& Technology, 41, 5224-5230.

Hoeganaes Corp., 1990. Friction Powder Grades. Riverton, NJ.

Hooton N.A., 1969. Metal-ceramic composites in high-energy fricyion applications. Bendix Technical Journal, Spring 1969, 55-61.

Hu Z., Shi J., Niu H. \& Cai Y., 2012. Synthetic musk fragrances and heavy metals in snow samples of Beijing urban area, China. Atmospheric Research, 104-105, 302-305.

Leśniewska B., Godlewska-Żyłkiewicz B., Boccab B., Caimib S.,Carolib S. \& Hulanicki A., 2004. Platinum, palladium and rhodium content in road dust, tunnel dust and common grass in Bialystok area (Poland): a pilot study. Science of the Total Environment, 321, 93-104.

Magill N. \& Sansalone J., 2010. Distribution of particulate-bound metals for source area snow in the Lake Tahoe watershed. Journal of Environmental Engineering, 136, 185-193.

Miguel E., Llamas J.F., Chacon E., Berg T., Larssen S., Royset O. \& Vadset M., 1997. Origin and patterns of distribution of trace elements in street dust: unleaded petrol and urban lead. Atmospheric Environment, 31, 2733-2740.

Newman L.B., 1978. Friction Materials - Recent Advances. Noyes Data Corporation, Park Ridge, NJ, 1978.

Nichollson G., 1995. Facts about Friction: A Friction Material Manual Almost All You Need to Know about Manufacturing. Gedoran, America Winchester, VA.

Österle W., Griepentrog M., Gross Th. \& Urban I., 2001. Chemical and microstructural changes induced by friction and wear of brakes. Wear, 251, 1469-1476.

Palacios M., Gomez U.M. \& Moldovan M., 2000. Assessment of environmental contamination risk by $\mathrm{Pt}, \mathrm{Rh}$ and Pd from automobile catalyst. Microchemical Journal, 67, $105-113$.

Reinosdotter K. \& Viklander M., 2005. A comparison of snow quality in two Swedish municipalities: Luleå and Sundsvall. Water, Air, \& Soil Pollution, 167, 3-16.

Sansalone J.J. \& Buchberger S.G., 1996. Characterization of metals and solids in urban highway winter snow and spring rainfall-runoff. Journal of the Transportation Research Board, 1523, 147-15.

Sansalone J.J., Glenn D.W. \& Tribouillard T., 2003. Physical and chemical characteristics of urban snow residuals generated from traffic activities. Water, Air, \& Soil Pollution, 148, $45-60$.

Schauer J.J., Lough G.C., Shafer M.M., Christensen W.F., Arndt M.F., DeMinter J.T. \& Park J.S., 2006. Characterization of metals emitted from motor vehicles. Health Effect Institute Research Report, 133, 1-88.

Sloss Industry Coporation [no year]. PMF® Fiber - The preferred Reinforcement in Friction Products. Birmingham. 
Vasić M.V., Mihailović A., Kozmidis-Luburić U., Nemes T., Ninkov J., Zeremski-Škorić T. \& Antić B., 2012. Metal contamination of short-term snow cover near urban crossroads: Correlation analysis of metal content and fine particles distribution. Chemosphere, 86, 6, 585-592.

Viskari E.L., Rekilä R., Roy S., Lehto O., Ruuskanen J. \& Kärenlampi L., 1997. Airborne pollutants along a roadside: assessment using snow analyses and moss bag. Environmental Pollution, 97, 153-160.

Westerlund C. \& Viklander M., 2006. Particles and associated metals in road runoff during snowmelt and rainfall. Science of The Total Environment, 362, 143-156.

Wieszała R. \& Wyciślik A., 2008. An attempt to identify the dust formed by frictional elements of vehicles in road condition. Journal of Engineering. Annals of Faculty of Engineering Hunedoara, 6, 143-148.

Wieszała R., 2006. Wpływ czynników eksploatacyjnych na poziom zanieczyszczeń w trakcie eksploatacji pojazdów [The influence of exploitation factors on the pollution lever during car exploitation]. Poland, Gliwice [Ph.D. thesis, unpublished]. 